\title{
How to measure the impact of social innovation initiatives?
}

Jorge Cunha. ALGORITMI Research center (University of Minho, Portugal)

jscunha@dps.uminho.pt

Paul Benneworth. CHEPS (University of Twente)

p.benneworth@utwente.nl

\author{
Series Editor Contact: \\ University of Twente \\ P.O. Box 217 \\ 7500 AE Enschede \\ The Netherlands \\ $\mathrm{T} \quad+3153-4893263$ \\ F $\quad+3153-4340392$ \\ E p.benneworth@utwente.nl \\ W www.utwente.nl/cheps
}

Paul Benneworth, Katharina Lemmens-Krug \& Franziska Eckardt

Centre for Higher Education Policy Studies 


\section{Table of Contents}

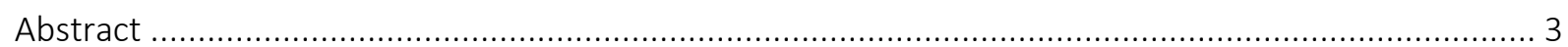

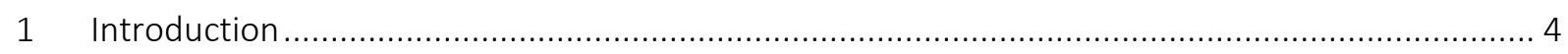

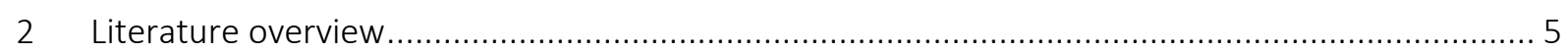

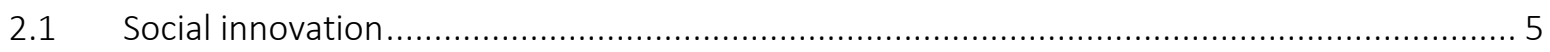

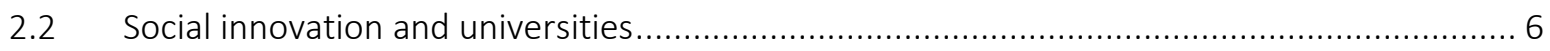

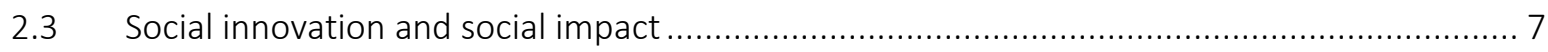

3. Proposing a framework to capture social innovation's multiple dimensions................................. 8

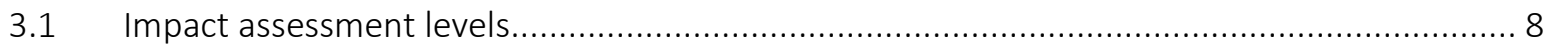

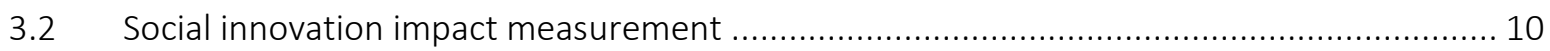

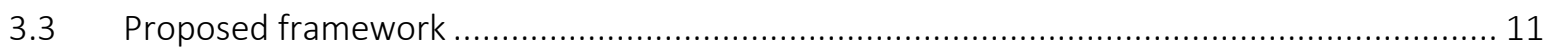

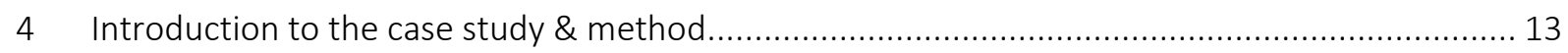

4.1 The University of Twente stimulating socially responsible innovation .................................. 13

4.2 A quick-scan of university contribution to social innovation ........................................ 14

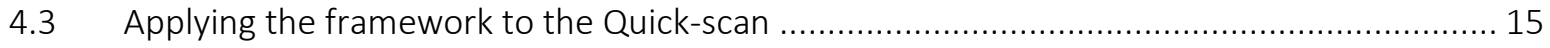

5 The value added of a social innovation impact measurement framework ................................ 20

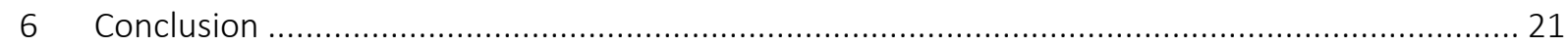

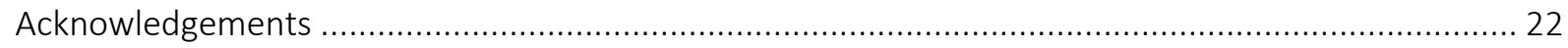

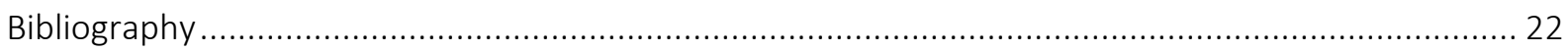




\begin{abstract}
Academic literature about the idea of social innovation grew sharply over the last decade, with researchers trying to define its concept and presenting several examples of successful social innovations. However, to support the development of social innovation initiatives is important to have a conceptual framework that al-lows evaluating its true impact. The purpose of this paper is to identify the boundary conditions for an effective set of social innovation indicators, which will help to have a more informed decision-making process. The main conclusion is that the impact of social innovations can be conceived as a set of results that manifests itself through different time periods, at different spatial scales, and must take into account the value experienced by all stakeholders involved. Thus, since a positive social innovation outcome depends on diverse factors and conditions, being most often context-dependent, it means that rather than imposing a specific set of indicators, based on a 'one-size-fits-all' approach a measuring process procedure should be adopted to assess the impact of social innovations.
\end{abstract}

Keywords: Social innovation, Universities, Impact assessment, Conceptual framework. 


\section{Introduction}

The idea of social innovation has emerged as an attempt to capture and describe bottom-up phenomena where new ideas, approaches, techniques and organizational forms grew from humble roots into substantive new social capacities contributing to social change and social development (Juliani, Silva, Cunha \& Benneworth, 2017). However, despite conceptual developments regarding social innovation, there is a lack of research about the process dimension of social innovation and, particularly, about the role universities might play in that process (Benneworth \& Cunha, 2015). In fact, there has been a failure in university-society engagement literature to address social innovation arguably related to problems in finding quick indicators to capture performance. Although universities' activities around technology transfer and knowledge exchange (and how this process develops) is well understood (Perkmann et al, 2013), other kinds of university knowledge contributions to drive wider societal development is less well understood (Cunha \& Benneworth, 2013). Social innovation is an important mechanism by which universities can contribute to socially sustainable development.

Universities now increasingly being pushed to demonstrate their value to society (Benneworth, 2013). Often, the question that arises is: how can universities measure the impact of their activities to society? This has led universities to progressively increase the use of indicators to monitor the value they deliver to their stakeholders and wider society, as well as for internal optimization purposes. Most indicators are primarily focused on economic and technological dimensions (Dainiene \& Dagiliene, 2015) others type of indicators (related to, for example, social, cultural or environmental dimensions) are used much less frequently. This bias appears justified by the notion that what is important is what can be measured, as what can be measured can be managed and steered. However, this reasoning brings us to the problem of whether what is measured actually is important, and the problem of good non technological-economic indicators, particularly important in social innovation.

There is almost no agreement on what kind of indicators or metrics might capture or allow the evaluation of social innovation and its impact (Nicholls, 2015). Social innovations are cross-sectoral and cross-disciplinary, involving actors at a range of various spatial scales, focusing on creating social value and community development, making them difficult to measure (Baturina \& Bezovan, 2015). Phills, Deiglmeier and Miller (2008) note that social innovation most often produces something intangible, such as a principle, an idea, a piece of legislation, a social movement, or a civic intervention, rather than tangible output (e.g. a product, process or technology). Measuring social innovation has not yet progressed the level of metrics used for technological and/or economic innovation (e.g. R\&D expenditure, number of patents, graduates in science and technology, value added). 
The growing importance of social innovation within policy circles and academia makes it important to explore how indicators can be applied and to overcome existing metrics' narrow focus on economic issues (Bund et al., 2015). It is this question we address in this research paper, how can we develop metrics to understand the impacts universities create through their social innovation processes? To address this, we take two steps. We firstly propose a conceptual framework model to identify the boundary conditions for an effective set of social innovation indicators, which will help to have a more informed policy decision-making process. We then apply this framework to the case of a university committed to promoting social innovation. In doing so, we reflect on and suggest potential refinements and improvements to the proposed framework.

The remainder of the paper is organised as follows. Section 2 presents a brief literature overview, focusing the concept of social innovation, the involvement of universities on promoting and fostering social innovation initiatives, and the social impact of social innovation. In Section 3, the proposed conceptual framework to capture social innovation's multiple dimensions is presented and explained, emphasising the need to capture time horizon and spatial scope of impacts. Section 4 presents a quick-scan of the University of Twente in the Netherlands, and uses the framework to analyse this scan. Section 5 identifies how such a framework might further be developed and also applied, and Section 6 concludes the paper and presents some avenues for further research.

\section{Literature overview}

\subsection{Social innovation}

The importance of innovation for business competitiveness and economic growth is widely established (Korez-Vide \& Tominc, 2016, OECD, 2007). The literature on the role of innovation in generating social change and addressing pressing social challenges and problems is relatively recent (Singh \& Majumdar, 2015). Social innovation has gained momentum recently, offering a way to respond to a context of significant crises where traditional approaches (either via market or public sector) were unable to provide adequate answers to acute problems or to entirely new challenges (BEPA, 2014). Social innovation should be understood not only as activities aimed at solving social problems (e.g. phenomena of social exclusion, poverty, lack of well-being, unemployment, and underdevelopment) but also as a process that relies heavily on actions developed by collaborative networks from bottom up actions, which may occur intentionally or emerge from a process of social change without prior planning (Rodrigues, 2017). Thus, social innovation plays a central role in social change processes balanced between values of equality and solidarity and economic issues, contributing to social inclusion and sustainable development. For an initiative, practice or action to be considered as social 
innovation should be focused on reducing inequalities, promoting quality of life and achieve inclusive societies. We here adopt Benneworth and Cunha's (2015) definition of social innovation:

"A social innovation is a socially innovative practice that delivers socially just outcomes by developing novel solutions in border spanning learning communities thereby creating social value by promoting community development, hence forming wider collaborative networks, and challenging existing social institutions through this collaborative action" (p. 512).

Although social innovation has been seen as a practice led field (Choi \& Majumdar, 2015), analytic empirical study of social innovation remains limited: there is much description and much theorisation, but relatively little theoretically informed empirical research. A number of examples of social innovations in different places and contexts have emerged reflecting new and innovative ways to address social challenges. Yet, this diversity of examples and practices makes social innovation difficult to describe, analyze and measure, given that social innovations vary across different communities, countries or cultures.

\subsection{Social innovation and universities}

Cunha, Benneworth and Oliveira (2015, p.629) contend that there is an "absence of any real systematic consideration of how universities contribute to the social innovation process". However, universities are important sources of knowledge for society, and they should therefore be well-placed to support social innovation initiatives or actions addressing (knowledge-intensive) societal challenges of the 21st century. Universities could potentially play an important role in terms of local community development in support of civil society, contributing to enhance human and social capital, improve capacity building, and to develop an active citizenship.

Benneworth and Cunha (2015) proposed a conceptual framework model to understand the process of social innovation and identify how and where universities might make contributions. This model is a double loop model; the first loop is a cycle in which a one-off demonstrator is created, through a process involving (a) idea generation (involves inventing a solution to a previously-identified social problem), (b) implementation (stakeholders need to be enrolled to support the promising and potentially risky new idea), (c) demonstrator (helps convince stakeholders of the idea's validity), . The second loop involves upscaling the social innovation beyond the original location, and involves (a) upscaling (finding ways to upscale the innovative solution and deliver wider societal benefits), (b) building a support coalition (using networks to bring together institutions to assist with the upscaling), and (c) codification (the social innovation becomes a product that can easily be implemented in many new settings, places or circumstances, allowing its upscaling). 
Benneworth and Cunha's (2015) framework was designed to offer a framework to understand how universities can contribute to the different stages of the social innovation process,. For that purpose, those authors have identified a typology of universities' resources that could offer a functionality that could contribute productively to the social innovation process. Those resources might involve staff time ( academic researchers, administrators and students), providing to access facilities (e.g. lecture rooms, science shops), university-specific expertise (technology transfer officers, accounting staff), financial resources, and managers/decision-makers. These resources may become contributed to these different stages of the process as social entrepreneurs seek to address the problems, uncertainties and challenges they undergo in seeking to progress their idea into a social change. Juliani, Silva, Cunha and Benneworth (2017) applied this conceptual framework to in the context of a case of a project undertaken by a Brazilian university, emphasising the importance of the social entrepreneur outside the university in delivering the change and the need for the university to establish a mutual self-interest with the beneficiaries of the social innovation.

\subsection{Social innovation and social impact}

The absence of a well-defined convergent notion with clearly distinguished characteristics makes social innovation difficult to measure. Indeed there is a sense in which social innovation has become a "policy concept" (Böhm \& Gløersen, 2011) where the presence of multiple definitions has been part of its popularity as many different communities have seen in it what they find useful. . Since social innovations are context-dependent, cross-sectoral, cross-disciplinary, and cross-geographical (Benneworth \& Cunha, 2015), characterizing them and applying analytical models is difficult, particular in ways that help to understand their 'value' and measure their 'impact'. Measurement is often based upon case study analysis, which undermines the comparability of those results. But there is a need to understand comparably the relative impact of social innovation initiatives or practices if they are to be systematically supported. Indicators are important because they help to build a knowledge base by assessing and evaluating what works, guide social investment decisions, and shape public policy (Baturina \& Bezovan, 2015). But although the purpose of social innovation is typically social value creation, current social innovation impact indicators used are largely derived from established economic models and value measures (such as shadow pricing). Consequently, social innovation decision-making process may be limited in terms of incorporating a full range of social risks and social returns (Antadze \& Westley, 2012).

Different approaches and methods have been proposed to evaluate social innovation initiatives (Krlev et al., 2014). However, the diversity of approaches makes it difficult to compare their impact, particularly where there can be a lack of clarity, along with the complexity of social problems and solutions proposed, and the intangibility of results obtained (Antadze \& Westley, 2012). The use of indicators on some kind of comparative basis to assess impact remains important, because they help 
to build a knowledge base on those social innovation initiatives that really work (Preskill \& Beer, 2012), but also because they can assist public decision-makers in formulating better public policies in the promotion of social innovation initiatives, and supporting the efforts of social organizations (Bund et al., 2015).

Currently, most approaches used (e.g. social return on investment; social impact assessment) are based on a similar reasoning to that used in the traditional cost-benefit analysis in economics now applied to initiatives of a social nature (Esteves et al., 2012). An assumption of those approaches is that what can be measured is what can be evaluated, and more perniciously, what can be measured is what should be evaluated (Millar \& Hall, 2013). However, the social impact of social innovation initiatives is much more intangible than technical innovations, particularly those that lead to the creation of new products or services whose impacts can be captured through sales figures. This helps explain the relative paucity of approaches measuring social innovation impact (Nicholls, 2015). Social innovation in a change that comes about as a result of linkages between complex phenomena, social processes, and involves differentiated outcomes (Nicholls \& Dees, 2015). Ultimately, the major difficulty in measuring social innovations' impact of social innovations relates to the fact that efforts are being made to measure the improvement in people's subjective well-being rather than economic wealth.

\section{Proposing a framework to capture social innovation's multiple dimensions.}

\subsection{Impact assessment levels}

In this paper we are concerned with measuring the impact of universities' involvement in social innovation initiatives or practices, and we therefore start this by making a conceptual distinction between the level of impacts. The first level is related to the micro-practices by which university researchers interact with social innovators. The micro impact of social innovations is focused on increasing people's well-being (the direct beneficiaries of the social innovation) by overcoming previously identified social problems or needs that remained unaddressed by the traditional public or private sectors. Researchers, with the resources at their disposal, can either become social innovators themselves or help other social innovators outside the university in developing new solutions for those social problems (Benneworth \& Cunha, 2015). The potential of universities to foster social change at the micro level derives from its civic engagement with local communities, at the grassroots and the local level where awareness emerges of social problems (Baturina \& Bezovan, 2015). This reflects the 
fact that many social innovation initiatives or practices emerge as direct and pragmatic response to needs experienced by individuals or groups in their daily life.

A second level of analysis relates to the meso-activities by which universities facilitate and encourage social innovation upscaling and diffusion. Frequently social innovation emerges at the local level from sharing and networking between a wide range of actors, and universities have all kinds of resources and assets potentially able to support a wide range of community development processes beyond the business sphere (Benneworth, 2013). Thus, engagement between universities as institutions and local communities can be a source of important social innovations, leading to a change on the way local communities function and promoting sustainable local development. Universities can play an important role in building social capital as a result of their involvement with the local community, being facilitators of social learning and contributing for the development of local social systems (Baturina \& Bezovan, 2015).

This leads to the third level of analysis - the macro-outcomes by which localities develop socially and change via of the successful implementation of social innovation initiatives or practices. The upscaling of a social innovation means that more individuals or organizations are involved in implementing that solution in new settings, places or circumstances (Benneworth \& Cunha, 2015). Hence, the social innovation diffuses through society and the scope of the solution grows, solving these problems in other places as these new forms of social organization spread through networked collaborative approaches. For this systematic change in society to be fully accomplished public policy decisionmakers have an important role by creating a supportive environment (Benneworth \& Cunha, 2015). Baturina and Bezovan (2015) highlighted that social innovations drive systemic change by transforming the ways in which societies think and thereby making possible new forms of social relations embodying more desirable power relations..

This distinction about the levels of analysis is important because it highlights that presence of different kinds of indicator users: providing information for people involved in social innovation in universities to improve it, for universities at the institutional level to understand their impact, and for policymakers to create supportive environments. In this context, user engagement, stakeholder involvement, and policy-makers' commitment in the process of social innovation is essential to achieve societal impact of social innovation. What is important in this context are the questions of why, when and how users are engaged within the process of social innovation and how that relates to the impact that those social innovations produced. 


\subsection{Social innovation impact measurement}

Esteves et al (2012) define social impact assessment as the effects of an activity on the society and its influence on the well-being of the individuals and households of a given community, something that emerges from the social changes that emerge from impact of social innovation initiatives or practices. The critical issue here is then one of flow; given particular levels of activity around social innovation, to what extent can a claim be made that that activity is indeed leading to those social changes, and that those changes are derived from the particular intervention, and whether the particular intervention has indeed derived from the wider institutional or policy framework which purports to promote it. Currently, there is no obvious standard for the measurement of the impact of social innovation initiatives and practices (Krlev et al., 2014). Some proposed approaches or indicators derive from those adopted to measure the impact of technological/economic innovation, but more generally, this wider question of how social innovation has affected the economy and society at large remains an under-researched topic (Howaldt et al., 2016). Purely economic measures tend to end up measuring the social economy, which although conceptually related to the idea of social innovation, is more concerned with non-profit business models rather than this wider issue of societal change (Millar \& Hall, 2013).

Notwithstanding, some authors (e.g. Antadze \& Westley, 2012, Reeder et al., 2012) contend that developing good metrics remains vital for supporting social innovation development, because the lack of a clear metric of effectiveness (such as profits or rate of return in the case of technological/economic innovation) makes it difficult for resources (either private or public) to flow to high-performing initiatives that are achieving the greatest social impact (Joy \& Shields, 2013). The claim is sometimes made that were it possible to define metrics for social innovation initiatives', this would help social investors and policy decision-makers to categorize the type of impact that various social innovations aim to achieve (Cabinet Office, 2013).

BEPA (2014) proposed four rationales for measuring the impact of social innovation initiatives or practices. Firstly, there is a need to prove that social innovation is an effective and sustainable way to respond to societal needs. Secondly, in order to justify the allocation of funds (either public or private), a common understanding of what the true impacts of social innovations are is necessary. Thirdly, evidence-based policies require ex-ante evidence of the expected impact of the actions involved. Finally, social innovation could open the way to developing a new competitive advantage for countries, showing that social value creation is central to achieve sustainable development.

Despite this imperative to measure impact, the practicalities of measuring social innovation's impact poses some challenges. Firstly, not only is the research on social innovation still in its early stages, 
social innovation processes themselves are regarded as complex and socially embedded (Bund et al. 2015). Secondly, data availability is a challenge, since there is no structured way to gather the data needed for evaluation (Preskill \& Beer, 2012). Thirdly, social innovation consists mainly in ideas, attitudes, practices or policies and does not necessarily result in the development of a product (Krlev et al., 2014). It most often consists of more social justice, more empowerment and more democracy which will contribute to a more dynamic and productive society (BEPA, 2010). Finally, there seems to be an insufficient culture for ex-post evaluation in the actors involved in the implementation of projects related to social innovation (Baturina \& Bezovan, 2015).

\subsection{Proposed framework}

Usually, as universities are not-for-profit organizations, they are well placed to create social value by promoting and/or supporting social innovation initiatives addressing social challenges, thus having a social impact that should be perceived and measured by all stakeholders. It should be recognized that this impact might be felt at different levels: micro-level (related to the impact on citizens and users), meso-level (focusing the impact on community and organizations), and macro-level (associated with the impact on society at large). We therefore frame the desirable indicator set around a conceptual model where indicators are useful for a range of internal and external stakeholders to better promote and support those social innovation opportunities.

As the European Commission/OECD (2015) emphasizes, a single metric cannot capture all the relevant impact derived from the implementation of a social innovation. Therefore, a holistic perspective should be adopted. For the design of this framework (see Figure 1), the process model of social innovation of Benneworth and Cunha (2015) was taken into account as well as a universities' stakeholders perspective on social missions of Benneworth and Jongbloed (2010). The heart of our framework is that the focus on the measurement process for the social impact of social innovation initiatives should facilitate identifying the boundary conditions for an effective set of indicators able to encompass the interests/objectives/concerns of all stakeholders. 
Conceptual framework for the measurement process of social innovation impact

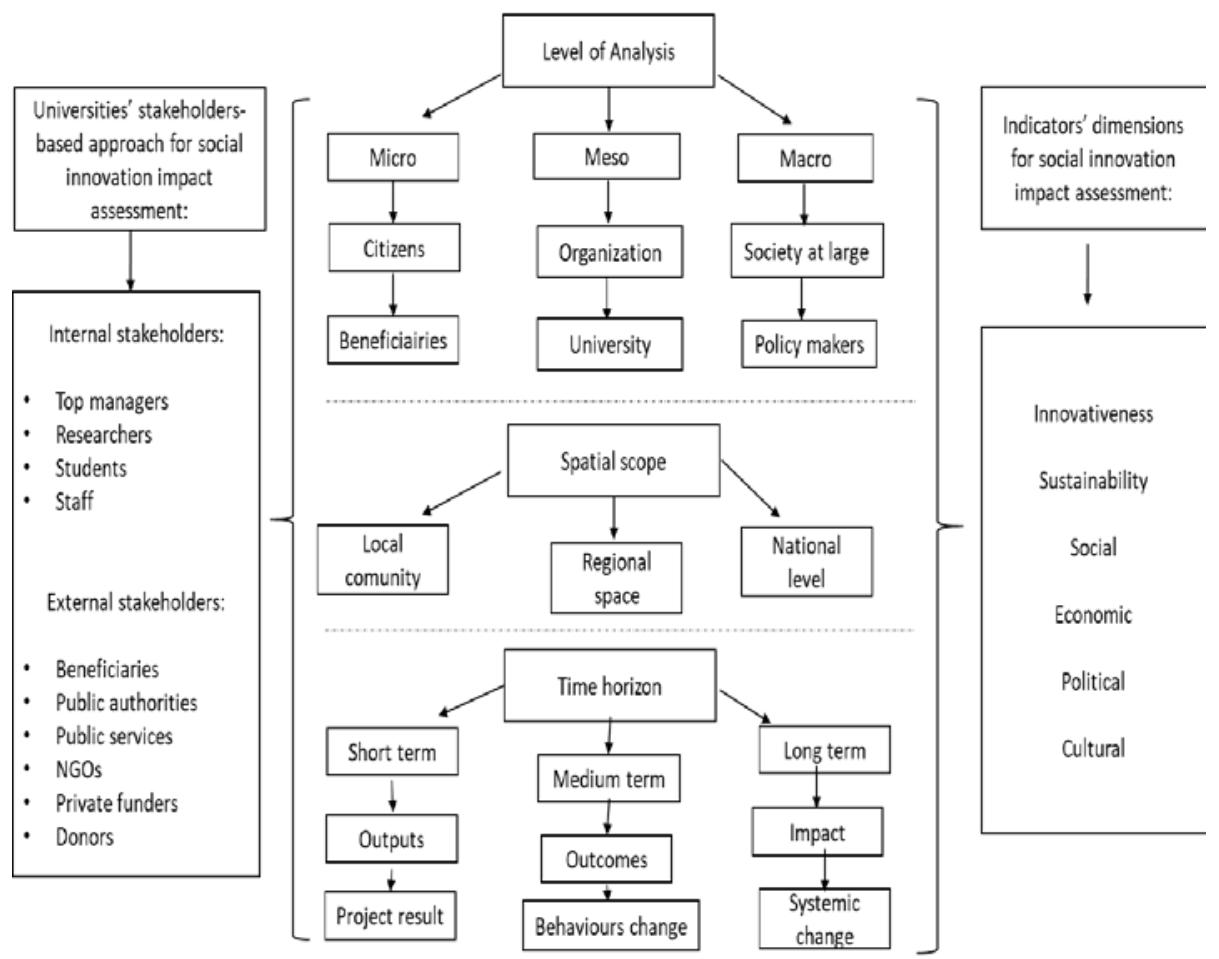

Fig. 1. Conceptual framework model for social innovation impact.

The impact of social innovations can be conceived as a set of results (most often intangible ones) that manifests itself through different time periods, at different spatial scales, and must take into account, particularly, the value experienced by beneficiaries and all stakeholders involved. Furthermore, a positive social outcome depends on diverse factors and conditions. This implies that fully capturing that impact demands a large set of indicators, categorized in a number of dimensions, and that those indicators should be identified at the outset of the analysis. Effectively measuring social impact in a way that serves the needs of these different stakeholders requires the use of both qualitative and quantitative methods, combining different tools and instruments. It is also important to account for the environmental situation as well: effective involvement by universities in social innovations requires finding a mutual interest in those activities, and simplistic measures can lead to universities disregarding opportunities for social innovation because their measurement system are not able to capture and recognise that value. 


\section{$4 \quad$ Introduction to the case study \& method}

To explore the use of this framework in practice and to assist with its further development, we apply it to a single organisation who at the time of writing had claimed to actively to contribute to promoting social innovation as a means to support the sustainable development goals. We selected the university as an example of an institution making serious efforts to stimulate social innovation, and at the same time having great difficulty in developing indicators for this innovation. Our case, the University of Twente, therefore represents an extreme case study where we expect the underlying tensions in measuring social innovation to come to the fore that may be less evident in other less ambitious universities.

\subsection{The University of Twente stimulating socially responsible innovation}

We have published extensively elsewhere on the studied university and its various societal impact activities, and this case study drew on both this existing knowledge (cf Benneworth et al, 2017; Benneworth \&Pinheiro, 2017) as well as work undertaken studying social innovation in Twente (see acknowledgements). We have used this to demonstrate how a relatively quick scan of available materials is available to provide a rough overview of social innovation within a university. In this quickscan, we look at four levels of the university, the institution, a faculty, an education course (an elective double module) and a single volunteer project. We turn to reflect on what the explanatory added value of the framework by considering the variables analytic level, spatial scope, time horizon, and the particular social innovation repertoires (see 2.2) that are supported by the university input.

The University of Twente is a small, technical university in the east of the Netherlands. Originally created in the 1960s to arrest the decline of the region's textiles industry, textiles subsequent collapse drove the university to seek out a new mission. In the 1970s, the university sought to encourage its academics to work with business and in the 1980s the university developed a funding scheme to encourage graduates to create their own companies to transfer university technologies into society. The university adopted the strapline "The entrepreneurial university" as part of a rebranding exercise in 1987, and the primary focus of its entrepreneurial and innovation activities in this period lay in exploiting technical knowledge.

Although the university had a number of social sciences faculties (through merger the number has changed over time) since the 1970s and was one of the university's two cores alongside technical science, the university's focus has long remained primarily technological. In 2010, the University rebranded once more, adopting this time the strapline "High Tech, Human Touch" as an allusion to the supposed importance of social as well as technological innovation for the university. The initial focus of this rebrand was initially in trying to technologize social innovation, but with a change in university leadership around 2014, more emphasis was placed on social innovation and putting a more diverse 
range of university knowledge into use towards solving grand challenges. In the following section, we present brief stylised accounts of how these changes have been implemented at four distinct levels of the institution, from the institution as a whole, through the faculties, into core activities and at the level of the project where the social innovation is created.

\subsection{A quick-scan of university contribution to social innovation}

In 2014 the university launched a new strategy Vision 2020, in which it set out a vision (core values) for the following five years (being socially relevant and making a difference, (b), creating excellence in combinations, (c) being entrepreneurial and pioneering, and (d) creating the global citizens of the future (Universiteit Twente, 2016). For the purposes of this paper, it is the first and last of those four elements which are relevant here, global citizens and social orientation, in which the university committed itself taking social and economic impact into account in its strategic decision-making, and educating students to have an international experience building on their existing networks. In the Autumn of 2018, the university management board table a policy note on the Socially Responsible University, and the University identified five new research themes that were intended to drive this, although social innovation was largely absent from these themes. The university also has awards for creative students to study these values (University Innovation Fellows), an €11.5m DesignLab allowing social partners to work with staff and students, an active programme to open up the campus to different communities (Living Smart Campus), and an annual Summer School (CuriousU to share these ideas with a wider group of participants.

The second level of activity is at the Faculty level, and for the sake of the quickscane we focus here on the larger of the two social science faculties, Behavioural \& Management Sciences (BMS). BMS Faculty signed up to the Principals of Responsible Management Education (PRME) in 2017, namely purpose, values, method, research, partnership and dialogue, and planned to launch annual student awards for SDG work as well as an annual SDG conference. The first of the activities within this was to compile what was termed a Sharing Information in Progress report, and this was in the process of being compiled at the time of writing. The SIP report identified the ways in which faculty teaching and research was contributing to the six PRME values and hence contributing directly or indirectly to SDGs. Social innovation emerged a number of times in the SIP report, including a Minor on Sustainable Supply Chain Management, contributions to the Summer School and a number of MOOCs that promote the PRME values for thousands of students internationally.

At the third level are university activities that contribute to social innovation (what is reported upon and aggregated in the PRME report). The university and faculty BMS have a number of these activities, including an entrepreneurship programme tailored for refugees (STAR-T) and a social 
entrepreneurship stimulation programme, both undertaken together with regional partners promoting innovation. The main activity we consider here is an elective course for third year undergraduate students created in 2014 with the merger of three smaller electives covering education for global development, field-study to the global south and social innovation (Crossing Borders). This elective involves sending c. 70 students annually to the global south to work in a volunteering organisation for an average of 3 months to deliver a socially beneficial project along with a dedicated research project exploring what can be learned from that project to address the global challenges.

At the fourth level are individual activities that emerge within these institutional frameworks that lead to individual micro-acts of social innovation. Continuing the example above of the Social innovation Minor, students work for 3 months for a volunteer organisation (typically a charity or nongovernmental organisation - NGO), using their university knowledge to support the NGO in their own activities, which may typically be about nature conservation, adult education, distributed energy generation or credit unions. The students may draw on central university resources to help cover their costs (up to $€ 500 / \$ 580$ from the Twente Mobility Funds). They may work on providing information, communications, marketing materials, educating/ teaching English, in community development projects and indeed in construction, water provision and distributed electronic generation. In this case, the students are able to contribute directly to the social innovation process as a resource; the students are not the innovators, but they facilitate the problem owners in the communities as they try to develop solutions to these problems and then in the NGOs as they try to upscale them and apply them in other situations. By reporting back to their supervisors in Twente, they also contribute to the supervisors' knowledge of social innovation and sustainable innovation, providing material supporting the supervisors' own research activities on social innovation (cf Mensing et al, 2018).

\subsection{Applying the framework to the Quick-scan}

It is possible to use the framework in 3.3 to provide a structure to the data to show how the various elements fit together. As a first step, we analyse each of the four levels in terms of the key dimensions salient to the framework, namely level, spatial scope, time horizon and then the innovation repertoires involved, and specifically the relationship between the university and the social innovation processes in the global south. As a second step, we attempt to render this data following the logic of the Framework, to present a cascading set of indicators for understanding the university contribution to social innovation. There are four levels of activity presented here, the institutional level, the faculty level, the activity level and the intervention level; most noteworthy is that it is the lowest of these levels (intervention) level by which the social innovation actually takes place. A summary is provided in Table 1, what is interesting from the perspective of developing a measurement framework is the 
way that these different levels interrelate, and in particular, the roles played by the highest levels in making possible the educational activity within which the social innovation is supported.

At the lowest level, the student interns work on placements in the global South for 2-4 months, contributing in various ways to ongoing social innovation projects. Because these projects are already ongoing, the students tend to contribution in three stages of the social innovation journey (see 2.2) namely, execution, demonstrator and upscaling phases. A typical execution activity is where one or more interns work in developing a new activity in a new location based on its own idea, such as a community centre with after-school care, distributed energy generation and off-grid sanitation. A typical demonstrator activity is when students work on demonstrating that these new activities have created benefits, such as in working on communities, marketing, public relations or business planning for NGOs as they seek to take what they perceive to be a success and to repeat it. A typical upscaling activity involves students participating in implementing what worked in one location elsewhere, for example implementing a community credit union/ education scheme to address open defecation practices.

In this, the student places a range of knowledge resources into the innovation process, represented in the working time on the project (calculated at between 320 and 600 hours) as well as the knowledge acquired in the degree programme to date, the orientating education activities and also from the supervisor. The student interns do not drive the innovation process, and the resources that they provide are not necessarily decisive in the social innovation process, but in the context of resourcelimited innovation contexts, they can be said to contribute meaningfully to these innovation processes. The intensity of the contribution is certainly comparable to technical students who become involved in technological innovation processes in for example their graduation projects undertaken in partnership with high-technology companies.

The remainder of the three levels are involved in shaping and orchestrating the flow of the resources into the innovation project, rather than the micro-scale arrangement for those resources (the student and their knowledge) into the social enterprise or NGO project. The education connects the social innovation activity with the economy of the university, in which resources flow to staff in return for providing accredited study points. The course documentation and accreditation process delivered by the course teachers facilitate this flow, enabling the activity. The faculty's commitment to the PRME principles (see 4.2) supports the validation of the course activity, and allows the activity to continue. At the level of the university, its commitment to educating global citizens in turn led the faculty to commit to adopting the PRME principles. 
The value of these higher level activities is instrumental, and in particular they permit something that is in essence peripheral to the University of Twente, namely social innovation, to become embedded in a way that allows more than 150 of these social innovation interventions to be delivered. These higher level interventions embed this peripheral activity into the level of the university. The activity transforms what is an external activity (students) doing social placements into something that fits with the institutional economy of the university (study points). The faculty SIP activities validate the module ad make the case that despite not having a fully academic content (roughly half of the study credit comes for doing 'non-academic' tasks) it warrants those study points. The strategic declarations of the university in turn led to the promulgation of those regulations that led to the faculty validating this peripheral activity.

There has been criticism of universities that make strategic declarations of serving global development interests, or of faculties that promulgate promotion policies that make community service a promotion option (Benneworth, 2013). What is important here is not the individual strategy, policy or Educational Module, but the overall linkage between the three allowing students to contribute to social innovation activities in the global south, and for that to become part of the university structure, thereby enabling its scalability. We show this in Figure 1, where we present an outline Map of how university contributions to social innovation could be presented. 
How to measure the impact of social innovation initiatives?

Table 1-An analysis of the Quick Scan using the tool proposed in 3.3

\begin{tabular}{|c|c|c|c|}
\hline Analytic level & Spatial Scope & Time Horizon & Social innovation repertoires \\
\hline Institution & $\begin{array}{l}\text { Global - partners } \\
\text { and beneficiaries } \\
\text { spread across globe }\end{array}$ & $\begin{array}{l}\text { Strategic programming } \\
\text { period of university ( } 6 \mathrm{yr} \\
\text { blocks) } 2015-2021\end{array}$ & $\begin{array}{l}\text { Creating an institutional space that declares that the university is open to } \\
\text { supporting social innovation } \\
\text { Highlighting potential research areas where university knowledge could } \\
\text { contribute to social innovation processes }\end{array}$ \\
\hline Faculty & $\begin{array}{l}\text { International - } \\
\text { partners and } \\
\text { beneficiaries spread } \\
\text { across globe }\end{array}$ & $\begin{array}{l}\text { Term of service of Dean }+ \\
\text { team (years) } \\
\text { Multi-annual ( } 2-3 \text { years) } \\
\text { planning processes }\end{array}$ & $\begin{array}{l}\text { Creating an accountability and self-reporting framework to track the } \\
\text { extent to which sustainable development is built into the curriculum } \\
\text { Creating recognition and acknowledgement for staff members who spend } \\
\text { their time doing work that contributes to the delivery of the SDGs }\end{array}$ \\
\hline $\begin{array}{l}\text { Education } \\
\text { module }\end{array}$ & $\begin{array}{l}\text { Global south plus } \\
\text { other locations } \\
\text { where SDG research } \\
\text { is taking place }\end{array}$ & $\begin{array}{l}\text { Medium-term } \\
\text { relationships with host } \\
\text { organisations } \\
\text { Annual course cycle - five } \\
\text { months of active teaching }\end{array}$ & $\begin{array}{l}\text { Academic researchers putting their knowledge to use to supervise } \\
\text { students working on projects to create local beneficiaries } \\
\text { University central resources providing bursaries to help support the } \\
\text { students to undertake the travel in which they deliver the socially } \\
\text { beneficial activity }\end{array}$ \\
\hline $\begin{array}{l}\text { Placement } \\
\text { project }\end{array}$ & $\begin{array}{l}\text { Inter-local } \\
\text { collaboration } \\
\text { networks: } \\
\text { University of Twente } \\
\text { Beneficiary location } \\
\text { Intermediary/ NGO } \\
\text { HQ locations }\end{array}$ & $\begin{array}{l}2-4 \text { months of student } \\
\text { being on placement } \\
\text { project and working to } \\
\text { deliver socially beneficial } \\
\text { activity }\end{array}$ & $\begin{array}{l}\text { Students work on social innovation projects, typically contributing to } \\
\text { either the implementation \& demonstrator phases (for self-standing } \\
\text { projects) or for upscaling (for established projects). } \\
\text { Students contribute time, labour power and knowledge to particular steps } \\
\text { of the innovation journey. } \\
\text { Individual academics provide their own knowledge of solving the } \\
\text { problems to provide a knowledge exchange from Twente to the host } \\
\text { location. }\end{array}$ \\
\hline
\end{tabular}

Source: authors' own design 


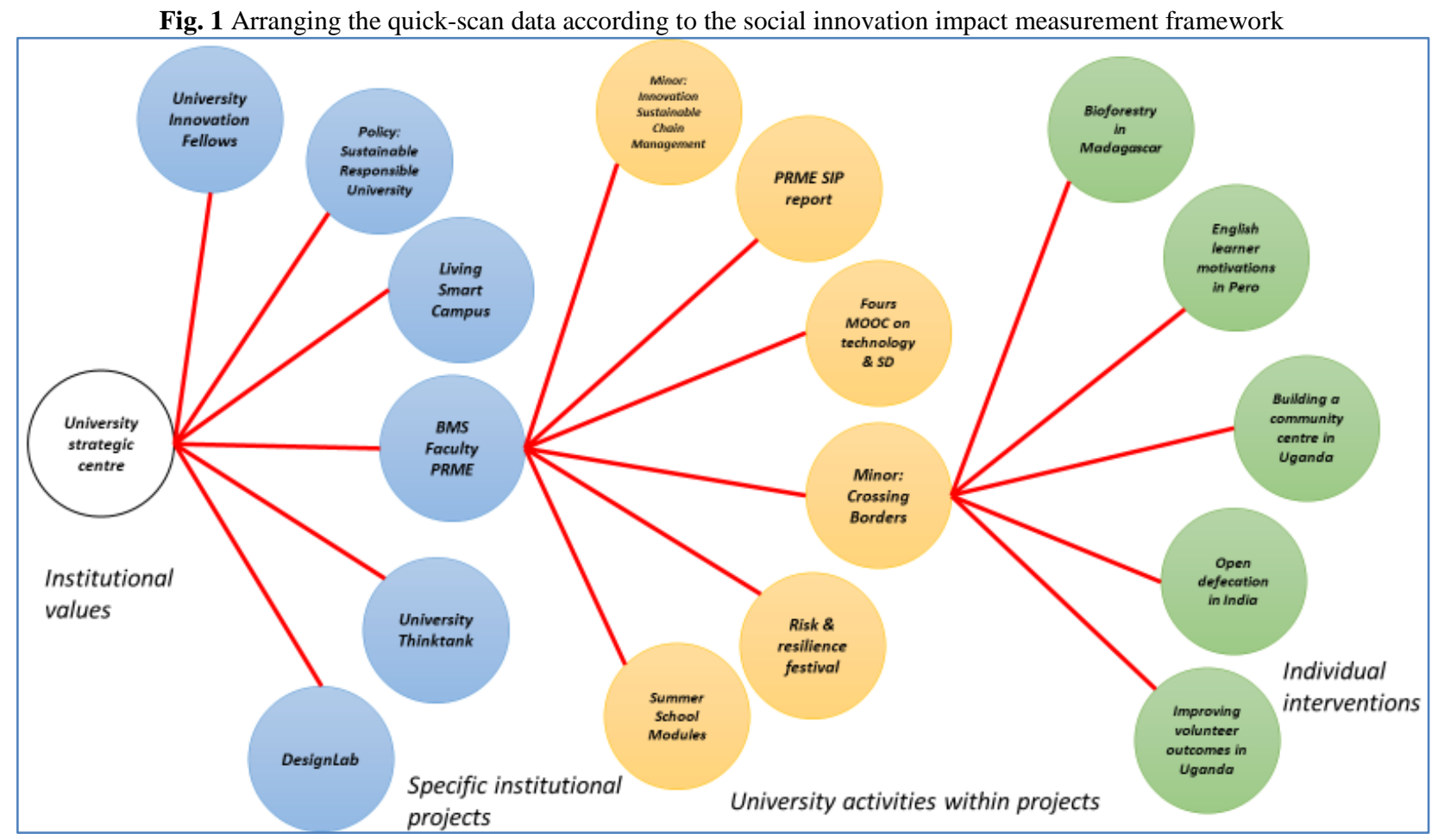

Source: authors' own design 


\section{The value added of a social innovation impact measurement framework}

The quick-scan and arrangement provided in section 4 provides a mechanism to reflect and suggest potential refinements and improvements to the proposed framework, with four main issues emerging. Firstly, the measurement of contribution to social innovation comes through measuring inputs to micro-impacts and attributing institutional contribution to those social innovation project outcomes. Secondly, we measure the value of the higher-level activities in terms of how they create frameworks that support the production of these micro-outcomes. Thirdly, it is possible at the institution level to produce a map of all the activities in different ways that relate (or not) to higher level strategies and policies: those avenues which branch down to the micro-level from the institutional indicate that these higher level activities are most valuable. Finally, what is not properly measured in this framework are the actual impacts of the social innovations, and more work is needed to create a link from universities making resources available to these social innovation outcomes. More reflections are provided on these points below.

Firstly, the primary measurement of value comes through the measurement of those micro-compacts, and in particular in tracing out the ways in which institutional resources contribute in various ways to supporting social innovation processes in practice. Because of the cascade method we have chosen, this has related to student and teacher time plus the resources from the Twente Mobility Fund, but it is possible to conceive of other ways that university resources might be made available to social innovation projects. Universities might for example might make their laboratory space or research projects more open to social innovation projects to help solve their problems, or indeed might make their incubation and technology transfer infrastructures open to social enterprises and entrepreneurship (which indeed is the case with one 'Living Smart Campus' project).

Secondly, the ways that the other levels should be measured relate to the extent that they create frameworks and architectures that allow resources to flow from the university to support these innovation projects. What is important is not the presence of strategies and pious statements by university managers or policies by administrative universities such as faculties, but the ways that these can be linked up with the facilitation of resource allocation. One element of measurement might be to trace these high level interventions down to the low level resource flows more comprehensively, and allow comparison between the different interventions, and indeed identify which strategic and administrative actions are not associated with resource flow antecedent to social innovation.

Thirdly, Figure 1 suggests a way of producing an institutional scan of social innovation practices, by linking up and tracing these various levels back to institutional frameworks. The topology of figure 1 allows the aggregation of these activities if fully traced to the institutional level in terms of the resource allocations that are made. But arguably more importantly would be that such a map would identify where there are missing links between the levels. One could imagine that there are strategic and administrative interventions that cannot be traced to particular social innovations in practice, or indeed that there are social innovation activities that are not supported institutionally. That would then allow a diagnosis to be made both of the overall magnitude of support for social innovation by the institution but also of where there are missing linkages that might in turn make the institution more efficient at supporting social innovation. 
A final remark is an important caveat that we must make in our reflections and the fact that we use

"resource input to social innovation" as a proxy for social innovation outcomes. We are cautious of trying to argue that institutions should be evaluated on the basis of processes which they do not have full control over - the universities have made the resources available to the social innovators and those social innovators may or may not succeed in delivering the innovation. But it would still be more satisfying to try to capture more than just the resource input to the social innovation process, potentially by looking at the phases of involvement or whether there was progress in the microactivities being undertaken, that could be captured without an additional bureaucratic burden.

\section{Conclusion}

Measuring the impact of universities' involvement in promoting social innovations is an increasingly urgent issue in view of the increasing pressure that universities are under to demonstrate that they are making adequate use of scarce resources at their disposal. At the same time, universities are increasingly being called upon to contribute to achieving sustainable development and for which social innovations can play a relevant role. Our contribution in this paper to addressing these issues is threefold. Firstly, we contribute to an emerging stream of literature that attempts to measure the impact of social innovation initiatives or practices. To accomplish this purpose, a conceptual framework model was proposed to measure that impact. This framework helps to identify the most valuable indicators for capturing and assessing social innovation impact, whilst recognizing that the selection of these indicators should be seen as an iterative process, establishing cause and effect relationships between actions (social innovation) and results and simplifying the complexity of the measurement process. Secondly, the proposed framework allows the identification of the boundary conditions for an effective set of social innovation indicators, recognizing that the measurement of social innovation impacts can be performed at different levels and for different stakeholders. Finally, we have applied the framework the case of a university that has recently sought to increase its emphasis on a core missions bringing together social innovation initiatives and university knowledge as a way of solving the $21^{\text {st }}$ century's grand challenges.

From the findings obtained with the case study analysis, it is possible to draw the following main conclusions. Firstly, the framework proposed seeks to give structure to social innovation impact measurement. Therefore, it can be seen as a useful tool for universities for guiding universities around the measurement process, but should not be perceived as rigid and is not intended to be exhaustive. It represents a first attempt to map the process of measurement and what can be obtained from the measurement system. Secondly, this framework (and the corresponding indicators) can help universities to gain an understanding of what social innovation initiatives are worthwhile to keep going supporting since it has an embedded robust approach regarding how they can be measured. Universities can meaqsure micro=-practices and then orchestrate them around an informational architecture that allows those outcomes and impacts at the micro-level to be linked to higher level decision-making and policies. This in turn helps to identify which elements of these high level interventions and policies are more or less successful, or at least influential, in creating social innovation outcomes. Thirdly, if universities are increasingly recognizing their social purpose and engagement with the community, they must be able to demonstrate they are capable of managing their social performance. In this context, it is also important to incorporate in the measurement process the perspective and expectations of universities' internal and external stakeholders. This poses several challenges for the measurement process as different stakeholders pursuit different 
aims. This would imply a dialogue between the university and its stakeholders in order to allow the successful implementation of the social innovation and its scalability.

\section{Acknowledgements}

This paper reports findings produced within the ESRC-funded project "Bringing Cambridge to Consett: university spin-off companies in the periphery" (RES-000-22-0659) along with a Research Councils UK Academic Fellowship in Territorial Governance. This paper also draws on work supported by the European Commission's Horizon 2020 research and innovation programme under Marie SkłodowskaCurie action grant agreement No. 722295, the RUNIN Project.

\section{Bibliography}

Antadze, N.; Westley, F. (2012) "Impact Metrics for Social Innovation: Barriers or Bridges to Radical Change?", Journal of Social Entrepreneurship, Vol. 3, No. 2, 133-150.

Baturina, D.; Bežovan, G. (2015) "Social Innovation Impact-review No. 9". Seventh Framework Programme (grant agreement 613034), European Union. Brussels: Third Sector Impact.

Benneworth, P. (2013) "The Evaluation of Universities and their Contributions to Social Exclusion" in P. Benneworth (ed.) University engagement with socially excluded communities, Dordrecht, Springer.

Benneworth, P. \& Cunha, J. (2015). Universities' contributions to social innovation: reflections in theory \& practice. European Journal of Innovation Management, 18(4), 508-527.

Benneworth, P., Jongbloed, B. (2010). "Who matters to universities? A stakeholder perspective on humanities, arts and social sciences valorisation". Higher Education, 59, 567-588.

Benneworth, P. \& Pinheiro, R. (2017) "Regional upgrading in the periphery: A view from the "rich" Northern European cousins" in M. Fonseca \& U. Fratesi (eds.) Regional Upgrading in Southern Europe: spatial dimensions and human capital, Dordrecht: Springer Verlag.

Benneworth, P. S. Pinheiro, R. \& Karlsen, J. (2017) "Strategic Agency and Institutional Change: Investigating the Role of Universities in Regional Innovation Systems (RISs)" Regional Studies 51 (2) pp. 235-248 doi: 10.1080/00343404.2016.1215599.

BEPA-Bureau of European Policy Advisers (2010) Empowering people, driving change: Social innovation in the European Union, Luxembourg: Publications Office of the European Union.

BEPA-Bureau of European Policy Advisers (2014) Social Innovation: A Decade of Changes, Luxembourg: Publications Office of the European Union.

Böhme, K. \& E. Gløersen (2011) Territorial cohesion storylines: Understanding a policy concept. Spatial Foresight Brief 2011:1.

Bund, E.; Gerhard, U.; Hoelscher, M.; Mildenberger, G. (2015) “A methodological framework for measuring social innovation. In: Historical Social Research 40, 3, pp. 48-78. 
Cabinet Office, Social Investment and Finance Team. (2013, May). Achieving social impact at scale: Case studies of seven pioneering co-mingling social investment funds. London, U.K

Choi, N.; Majumdar, S. (2015) "Social Innovation: Towards a Conceptualisation", in S. Majumdar et al. (eds.), Technology and Innovation for Social Change, Springer India.

Cunha, J.; Benneworth, P. (2013) Universities' contributions to social innovation: towards a theoretical framework, Paper presented at the EURA Conference 2013, 3-6 July, Enschede, The Netherlands.

Cunha, J.; Benneworth, P.; Oliveira, P. (2015) "Social entrepreneurship and social innovation: A conceptual distinction", in Handbook of Research on Global Competitive Advantage through Innovation and Entrepreneurship, Edited by L. Farinha, J. Ferreira, H. Lawton-Smith, and S. Bagchi-Sen, Publisher: IGI Global. Hershey, Pennsylvania.

Dainiene, R., Dagiliene, L. (2015). A TBL Approach Based Theoretical Framework for Measuring Social Innovations. Procedia - Social and Behavioral Sciences, 213, 275-280.

Esteves, A.; Franks, D.; Vanclay, F. (2012) "Social impact assessment: The state of the art", Impact Assessment and Project Appraisal, 30:1, 34-42.

European Commission/OECD (2015). "Policy Brief on Social Impact Measurement for Social Enterprises". Luxembourg: Publications Office of the European Union.

Howaldt, J.; Domanski, D.; Kaletka, C. (2016) "Social innovation: Towards a new innovation paradigm", Mackenzie Management Review, 17(6), 20-44.

Joy, M., \& Shields, J. (2013). Social impact bonds: the next phase of third sector marketization?. Canadian journal of nonprofit and social economy research, 4(2), pp. 39-55.

Juliani, D., Silva, A., Cunha, J. \& Benneworth, P. (2017). Universities' contributions to sustainable development's social challenge: A case study of a social innovation practice. International Journal of Social Ecology and Sustainable Development, 8(3), 1-18.

Korez-Vide, R; Tominc, P. (2016). Competitiveness, Entrepreneurship and Economic Growth. In P. Trapczynski et al. (eds.), Competitiveness of CEE Economies and Businesses, Springer International Publishing Switzerland 2016.

Krlev, G.; Bund, E.; Mildenberger, G. (2014) “Measuring What Matters-Indicators of Social Innovativeness on the National Level", Information Systems Management, 31:3, 200-224.

Millar, R.; Hall, K. (2013) "Social Return on Investment (SROI) and Performance Measurement", Public Management Review, 15:6, 923-941.

OECD (2007). Innovation and growth: Rationale for an innovation strategy.

Nicholls, A. (2015) "Synthetic Grid: A critical framework to inform the development of social innovation metrics", CRESSI Working Papers No. 14/2015.

Nicholls, A., Dees, J.G. (2015). "Social Innovation", In International Encyclopedia of the Social \& Behavioral Sciences (Second Edition), edited by James D. Wright, Elsevier, Oxford, Pages 355-361. 
Perkmann, M., Tartari, V., McKelvey, M., Autio, E., Broström, A., D’Este, P., Fini, R., Geuna, A., Grimaldi, R., Hughes, A., \& Krabel, S. (2013). Academic engagement and commercialisation: A review of the literature on university-industry relations. Research policy, 42(2), 423-442.

Phills, J., DeigImeier, K., Miller, D. (2008) “Rediscovering social innovation”. Stanford Social Innovation Review 6 (Fall).

Preskill, H.; Beer, T. (2012) “Evaluating social innovation”, Center for Evaluation Innovation.

Reeder et al. (2012) "Strengthening social innovation in Europe - Journey to effective assess ment and metrics", Directorate-General for Enterprise and Industry, European Commision.

Rodrigues, A. (2007). "Modelos de gestão e inovação social em organizações sem fins lucrativos: Divergências e convergências entre nonprofit sector e economia social”. Organizações \& Sociedade, 14(43), 111-128.

Singh A., Majumdar S. (2015). Technology and Innovation for Creating Social Change: Concepts and Theories. In: Majumdar S., Guha S., Marakkath N. (eds) Technology and Innovation for Social Change. Springer, New Delhi.

Universiteit Twente (2016) Vision2020: vernieuwen, experimenteren, pionieren, Enschede, University of Twente (mimeo). 
The Center for Higher Education Policy Studies (CHEPS) is a research institute (WHW, Article 9.20) located in the Faculty of Behavioural and Management Sciences within the University of Twente, a public university established by the Dutch government in 1961. CHEPS is a specialized higher education policy centre that combines basic and applied research with education, training and consultancy activities.

http://www.utwente.nl/bms/cheps/

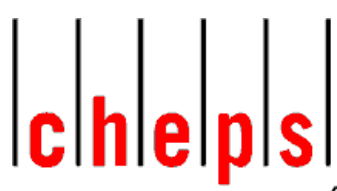

Center for Higher Education

Policy Studies 